\title{
Case reports: old-timers and evergreens
}

\section{A. Koch ${ }^{1,2,3,4^{*}}$ and T. Fülöp ${ }^{5}$}

After more than 11 years of service to the Journal of Medical Case Reports (JMCR), I am writing these lines with mixed feelings, as this has been a wonderful journey and I am now becoming an "old-timer"... or evergreen (Fig. 1). First, I wish to thank the editor Prof. Michael Kidd for his leadership and trust in me as a deputy editor of the journal. Furthermore, I wish to thank all the deputy editors, especially Profs. Richard Rison and Jean Karl Soler for their collegiality. Together, and with the leadership of Prof. David Riley, we launched the CARE (CAse REport) guidelines in 2013 [1, 2].

With the help of the editorial staff, JMCR has become a success, with increasing submissions from all over the world. Initially residing in Australia when $J M C R$ was launched, editor Prof. Kidd has now relocated to Toronto, Canada. I myself was born and raised in Nuremberg, Germany, and worked in the USA last from 2006 to May 2017 before relocating back to Germany. Since returning, I have encountered there an attitude change in physicians, with now less than $50 \%$ of medical doctors completing a dissertation compared to 25 years ago. Many younger physicians, but also, increasingly, older physicians, no longer trust statistical truth finder studies with conclusions that simply do not match up with the medical realities in individual patient care. On the other hand, many contemporary "scientific" medical studies with many known and unknown variables confirm what was already known, or is common sense, similar to the fact that one should typically not cross a red traffic light because an accident might happen (Shanks JA. Probability in action: the red traffic light. Journal of Statistical Education. 2007, Volume 15, Issue 1. https://www.tandfonline.com/doi/full/10.1080/10691898.2007.11889457).

As stated by me in 2009 (https://casesnetwork.wordpress.com/2009/05/01/christian-koch-interview/), we are in an era of "evidence-based medicine." However, we have finally begun to realize that much of the so-called evidence is derived from heterogeneous patient populations and is not necessarily applicable to our individual

\footnotetext{
* Correspondence: Christian.koch65@gmail.com

${ }^{1}$ Medicover GmbH, Berlin, Germany

${ }^{2}$ Carl von Ossietzky University of Oldenburg, Oldenburg, Germany

Full list of author information is available at the end of the article
}

patients we see on a daily basis. Numerous studies including ENHANCE, ACCORD, ADVANCE, the VA Diabetes Trial, and SPRINT have shown us that heterogeneity of patients, equipment, infrastructure, investigators, and so on can limit the successful gathering of evidence on a large scale; this makes us think about personalized, individualized medicine and that is why publishing case reports is important [3-5]. Many years ago, Prof. Ioannidis has provided insight why most published research findings are false [6]. In part, reasons for that lie in the way funding networks are set up / arranged which often does not promote innovation and real discovery, although this is frequently pretended. In times with limited science funding, reassessing the grading of scholarly productivity and the way scientists and clinician-scientists should be evaluated is in order to preserve academic institutions [7, 8]. "Medical science politicians," however, love to use trendy phrases like "patient explorer data warehouse," "outcomes research," and "big data analysis" without having learnt or, worse, despite knowing better, that the equation still remains "garbage in = garbage out." Data entry depends on a well-trained and highly precise medical professional with a mindset that is able to think outside the box. All this starts with fully understanding the medical condition of ONE individual patient and I strongly doubt that many of these grant-seeking "medical science politicians" have ever attempted to simply do that: completely understand everything about ONE patient and record it. The truth of clinical success is always tested in an $N=1$ patient; our credibility and trust as physicians is on the line with the one patient we see on the other side of the room. It is then and there that our training, years of dedication and hard work, experience, and clinical insight are tested, each day and every day.

The editor of $J M C R$, Prof. Kidd, not only had that vision but acted on it and launched JMCR in 2007 with obvious ongoing success [9-12]. Many other publishers followed suit and launched spin-off journals to publish case reports separately (American Journal of Case Reports, BMJ Case Reports, and many others). Conducting retrospective studies with less than 100 patients early in my academic career, I felt frustration at having to list 


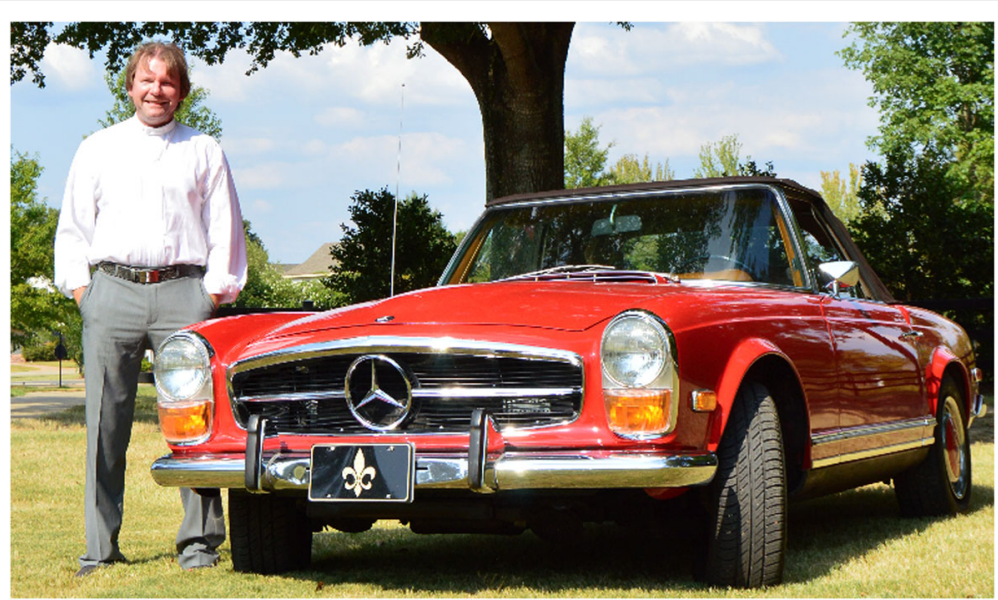

Fig. 1 Prof. Christian Koch, deputy editor at Journal of Medical Case Reports since 2007

every single case in table form and then perform statistics on this data because journal reviewers requested such analyses be done before articles were acceptable for publication. Worse, I encountered basic science researchers who conducted statistical analyses on seven or eight rat study samples, published such studies in high-impact journals, and then really thought of themselves as great scientists.

After leaving Germany to obtain residency training at the outstanding and comprehensive Ohio State University Medical Center, USA, under the chairmanship of Prof. Ernest Mazzaferri, I had the good fortune to work with excellent medical colleagues who always tried to fully understand the ONE patient [13-17]. I then had the honour to join the prestigious research team around my mentor Prof. George Chrousos at the National Institutes of Health in Bethesda, Maryland, USA [18-23]. There, I learned how to conduct laboratory science studies and apply them to the individual patient [24-29]. I remember vividly the endorphin rush running through my arteries when we had a case study accepted in the New England Journal of Medicine after the editor Dr Robert Utiger had corrected the manuscript [30]. After returning to Germany in 2002 to take on a highly prestigious state government position and completing the habilitation procedure to become eligible for a full professorship, I continued teaching medical students, interns, residents, fellows, and working with faculty members valuing the full and uncompromising understanding of one individual patient $[31,32]$. At that time, I had the pleasure to meet with a small group of outstanding clinical science endocrinologists who shared my view [33, 34], and we quickly discovered major "research studies," published in prestigious medical journals, that should perhaps be classified as "Mogelpackung" (research making big claims nicely wrapped up in a neat package). In 2006, I then returned to the USA to take on a position as full professor and director of the Division of Endocrinology, Diabetes, and Metabolism at the University of Mississippi Medical Center (UMMC). The challenge and opportunity there was the "open range" and evolving infrastructure. I could, therefore, become active in a wide array of endocrinological aspects and research and successfully launched and concluded several studies, including case studies [35-40]. What fellow

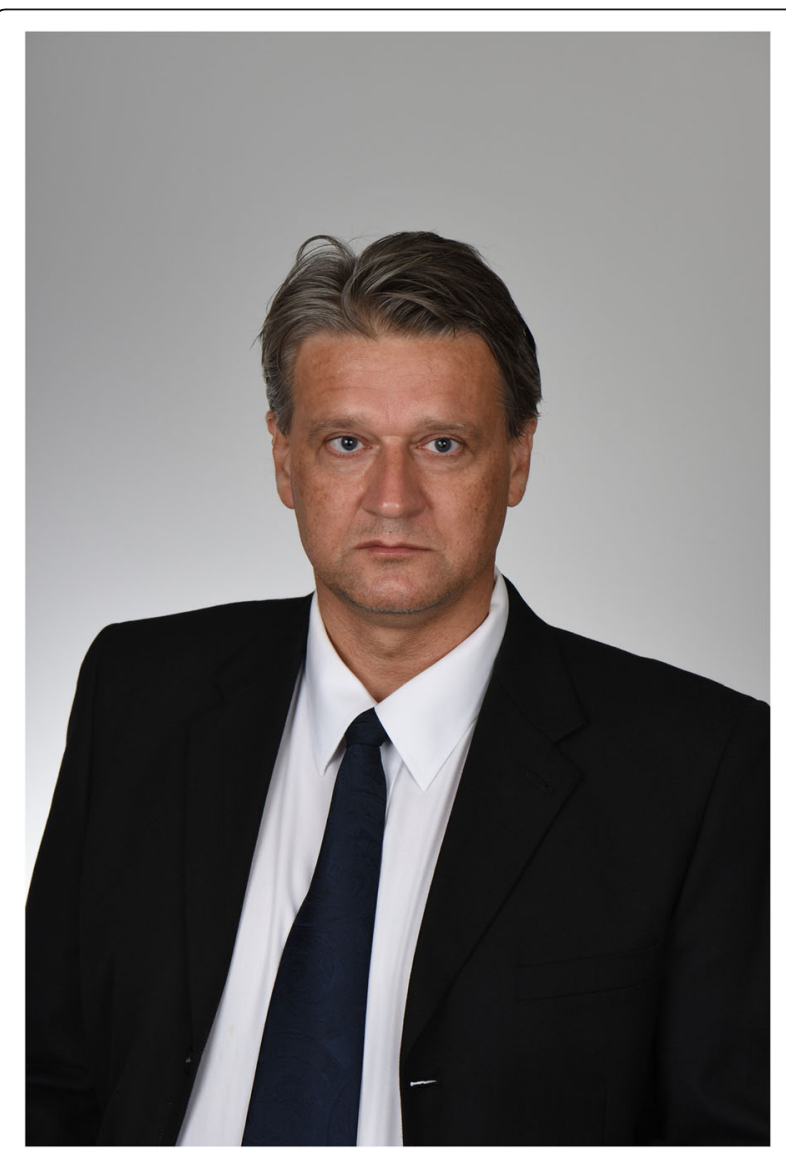

Fig. 2 Prof. Tibor Fülöp, Medical University of South Carolina, USA 
physicians and scientists need to understand is that textbook knowledge often cannot be applied to socioeconomically challenged communities with many patients presenting with advanced disease states that very few medical doctors have ever previously encountered in real life or in the medical literature. As much as I could, I tried to promote the vision of $J M C R$ and assisted in recruiting several UMMC faculty members to become associate editors, namely Drs Garla, Lien, Pound, Yanes, and Vick.

Around the time of my arrival at UMMC, Prof. Tibor Fülöp (Fig. 2) also joined the Medical Center as a faculty member and we started collaborating on various projects [41-45]. Prof. Fülöp is an outstanding internist, nephrologist, educator, and researcher who has the ability to think outside the box. It is therefore with great pleasure that I introduce him as a new deputy editor for $J M C R$. Prof. Fülöp has risen through the academic ranks from assistant professor, to associate professor, to full professor with tenure at UMMC. He then returned to his native Hungary to complete his $\mathrm{PhD}$ degree in 2015. Afterward, he joined the Medical University of South Carolina in the USA as a full professor of medicine in the Department of Medicine. I wish him the best of success in his journey with $J M C R$ and I am hopeful that he will enjoy the ride as much as I did, or more.

In conclusion, I would like to remind all potential authors that $J M C R$ does not only accept the zebras and black swans among patient encounters [46] but also follows the listed criteria (https://jmedicalcasereports.biomedcentral.com/about):

Case reports should show one of the following:

- Unreported or unusual side effects or adverse interactions involving medications.

- Unexpected or unusual presentations of a disease.

- New associations or variations in disease processes.

- Presentations, diagnoses, and/or management of new and emerging diseases.

- An unexpected association between diseases or symptoms.

- An unexpected event in the course of observing or treating a patient.

- Findings that shed new light on the possible pathogenesis of a disease or an adverse effect.

Suitable research articles include but are not limited to: $N$ of 1 trials, meta-analyses of published case reports, research addressing the use of case reports and the prevalence or importance of case reporting in the medical literature, and retrospective studies that include case-specific information (age, sex, and ethnicity) for all patients.

So long and many thanks for the ride!

\section{Christian Albert Koch.}

Authors' contributions

CAK drafted the manuscript and TF provided intellectual input. CAK and TF both read and approved the final manuscript.

\section{Authors' information}

Prof. Koch is affiliated with the Carl von Ossietzky University as well as the Technical University of Dresden, MK III (Chair, Prof. Stefan Bornstein), Germany. He also is adjunct professor at the University of Louisville, KY, USA, and works at Medicover GmbH Germany. Before June 2017, Koch had served as a professor of medicine (with tenure) at the University of Mississippi Medical Center in Jackson, MS, USA, and staff physician at the G.V. (Sonny) Montgomery VA Medical Center. He is a "summa cum laude" graduate of the Friedrich-Alexander University in Erlangen-Nuremberg, Germany and trained in neurosurgery, neurology, and internal medicine in Germany. He then completed a residency in Internal Medicine at the Ohio State University in Columbus, OH, USA, under the chairmanship of Prof. EL Mazzaferri, and clinical and research training in endocrinology at the National Institutes of Health in Bethesda, MD, USA, under the guidance of Prof. George P. Chrousos and many collaborating colleagues. Prof. Koch's research focus has been the pathogenesis of endocrine tumors and endocrine hypertension. He remains interested in translational and multidisciplinary research with questions arising from patient encounters, trying to explain clinical observations by looking at bench results to further improve patient care. In May 2017, the American College of Endocrinology awarded Prof. Koch the prestigious title of Master of the American College of Endocrinology (MACE) (https://www.umc.edu/news/Miscellaneous/2017/May/Endocrinologist-to-receive-prized-MACE--grad-students-fellows-earn-biology-honors.html).

\section{Competing interests}

Prof. Koch declares no direct conflict with this article. He has served on the Advisory Board of Novartis on the topic acromegaly and has participated in educational conferences on the topics neuroendocrine tumours and acromegaly sponsored by Novartis and Ipsen.

\section{Publisher's Note}

Springer Nature remains neutral with regard to jurisdictional claims in published maps and institutional affiliations.

\section{Author details}

${ }^{1}$ Medicover GmbH, Berlin, Germany. ${ }^{2}$ Carl von Ossietzky University of Oldenburg, Oldenburg, Germany. ${ }^{3}$ Technical University of Dresden, Dresden, Germany. ${ }^{4}$ University of Louisville, Louisville, KY, USA. ${ }^{5}$ Medical University of South Carolina, Charleston, USA.

Received: 1 October 2018 Accepted: 3 October 2018

Published online: 27 November 2018

References

1. Rison RA, Kidd MR, Koch CA. The CARE (CAse REport) guidelines and the standardization of case reports. J Med Case Rep. 2013;7:261.

2. Riley DS, Barber MS, Kienle GS, Aronson JK, von Schoen-Angerer T, Tugwell $\mathrm{P}$, Kiene $\mathrm{H}$, Helfand M, Altman DG, Sox H, Werthmann PG, Moher D, Rison RA, Shamseer L, Koch CA, Sun GH, Hanaway P, Sudak NL, Kaszkin-Bettag M, Carpenter JE, Gagnier JJ. CARE guidelines for case reports: explanation and elaboration document. J Clin Epidemiol. 2017:89:218-35.

3. Wells R, Rahman M. SPRINT and the Kidney: What Have We Learned? Curr Hypertens Rep. 2018;20(11):95.

4. Jordan J, Kurschat C, Reuter H. Arterial Hypertension. Dtsch Arztebl Int. 2018; 115(33-34):557-68.

5. Hannah-Shmouni F, Melcescu E, Koch CA. Testing for Endocrine Hypertension. In: De Groot LJ, Chrousos G, Dungan K, Feingold KR, Grossman A, Hershman JM, Koch C, Korbonits M, McLachlan R, New M, Purnell J, Rebar R, Singer F, Vinik A, editors. Endotext [Internet]. South Dartmouth (MA): MDText.com, Inc.; 2000-2016 Dec 30. https://www.ncbi. nlm.nih.gov/books/NBK278965/.

6. Ioannidis JP. Why most published research findings are false. PLoS Med. 2005;2(8):e124.

7. Ioannidis JPA. Science funding is broken. Sci Am. 2018:319(4):76.

8. Moher D, Naudet F, Cristea IA, Miedema F, loannidis JPA, Goodman SN. Assessing scientists for hiring, promotion, and tenure. PLoS Biol. 2018;16(3): e2004089. 
9. Kidd M, Hubbard C. Introducing Journal of Medical Case Reports. J Med Case Rep. 2007;1:1.

10. Rison RA, Shepphird JK, Kidd MR. How to choose the best journal for your case report. J Med Case Rep. 2017;11(1):198.

11. Rison RA. How to write a neurology case report. J Med Case Rep. 2016;10:9.

12. Rison RA. A guide to writing case reports for the Journal of Medical Case Reports and BioMed Central Research Notes. J Med Case Rep. 2013;7:239.

13. Koch CA, Mabee CL, Robyn JA, Koletar SL, Metz EN. Exposure to domestic cats: risk factor for Pasteurella multocida peritonitis in liver cirrhosis? Am J Gastroenterol. 1996;91(7):1447-9.

14. Koch CA, Mazzaferri EL, Larry JA, Fanning TS. Bullous pemphigoid after treatment with furosemide. Cutis. 1996;58(5):340-4.

15. Koch CA, Fontana ME, Mazzaferri EL. Exercise intolerance and ankle edema in a young woman. Hosp Pract (1995). 1997;32(2):190-6.

16. Koch CA, Archer TP, Kraut EH. Myocardial ischemia in a patient with chronic refractory idiopathic thrombocytopenic purpura. Arch Intern Med. 1997; 157(22):2668.

17. Koch CA, Robyn JA, Coccia MR. Systemic lupus erythematosus: a risk factor for pneumonia caused by Legionella micdadei? Arch Intern Med. 1997; 157(22):2670-1.

18. Chrousos GP, Vingerhoeds A, Brandon D, Eil C, Pugeat M, DeVroede M, Loriaux DL, Lipsett MB. Primary cortisol resistance in man. A glucocorticoid receptor-mediated disease. J Clin Invest. 1982;69(6):1261-9.

19. Chrousos GP, Schulte HM, Oldfield EH, Gold PW, Cutler GB Jr, Loriaux DL. The corticotropin-releasing factor stimulation test. An aid in the evaluation of patients with Cushing's syndrome. N Engl J Med. 1984;310(10):622-6.

20. Latronico AC, Anasti J, Arnhold IJ, Rapaport R, Mendonca BB, Bloise W, Castro M, Tsigos C, Chrousos GP. Brief report: testicular and ovarian resistance to luteinizing hormone caused by inactivating mutations of the luteinizing hormone-receptor gene. N Engl J Med. 1996;334(8):507-12.

21. Koch CA, Bornstein SR, Chrousos GP, Stratakis CA. Primary pigmented nodular adrenocortical dysplasia (PPNAD) within the scope of Carney complex as the etiology of Cushing syndrome. Med Klin (Munich). 2000; 95(4):224-30.

22. Dynkevich Y, Rother KI, Whitford I, Qureshi S, Galiveeti S, Szulc AL, Danoff A, Breen TL, Kaviani N, Shanik MH, Leroith D, Vigneri R, Koch CA, Roth J. Tumors, IGF-2, and hypoglycemia: insights from the clinic, the laboratory, and the historical archive. Endocr Rev. 2013;34(6):798-826.

23. Koch CA, Azumi N, Furlong MA, Jha RC, Kehoe TE, Trowbridge CH, O'Dorisio TM, Chrousos GP, Clement SC. Carcinoid syndrome caused by an atypical carcinoid of the uterine cervix. J Clin Endocrinol Metab. 1999;84(11):4209-13.

24. Huang SC, Koch CA, Vortmeyer AO, Pack SD, Lichtenauer UD, Mannan P, Lubensky IA, Chrousos GP, Gagel RF, Pacak K, Zhuang Z. Duplication of the mutant RET allele in trisomy 10 or loss of the wild-type allele in multiple endocrine neoplasia type 2-associated pheochromocytomas. Cancer Res. 2000;60(22):6223-6.

25. Vortmeyer AO, Huang SC, Koch CA, Governale L, Dickerman RD, McKeever PE, Oldfield EH, Zhuang Z. Somatic von Hippel-Lindau gene mutations detected in sporadic endolymphatic sac tumors. Cancer Res. 2000;60(21): 5963-5.

26. Koch CA, Huang SC, Zhuang Z, Stolle C, Azumi N, Chrousos GP, Vortmeyer AO, Pacak K. Somatic VHL gene deletion and point mutation in MEN 2Aassociated pheochromocytoma. Oncogene. 2002;21(3):479-82.

27. Huang SC, Torres-Cruz J, Pack SD, Koch CA, Vortmeyer AO, Mannan P, Lubensky IA, Gagel RF, Zhuang Z. Amplification and overexpression of mutant RET in multiple endocrine neoplasia type 2-associated medullary thyroid carcinoma. J Clin Endocrinol Metab. 2003;88(1):459-63.

28. Koch CA, Vortmeyer AO, Diallo R, Poremba C, Giordano TJ, Sanders D, Bornstein SR, Chrousos GP, Pacak K. Survivin: a novel neuroendocrine marker for pheochromocytoma. Eur J Endocrinol. 2002;146(3):381-8.

29. Uwaifo Gl, Koch CA, Hirshberg B, Chen CC, Hartzband P, Nieman LK, Pacak $K$. Is there a therapeutic role for octreotide in patients with ectopic Cushing's syndrome? J Endocrinol Investig. 2003;26(8):710-7.

30. Koch CA, Doppman JL, Watson JC, Patronas NJ, Nieman LK. Spinal epidural lipomatosis in a patient with the ectopic corticotropin syndrome. N Engl Med. 1999:341(18):1399-400.

31. Miehle K, Tannapfel A, Lamesch P, Borte G, Schenker E, Kluge R, Ott RA, Wiechmann V, Koch M, Kassahun W, Paschke R, Koch CA. Pancreatic neuroendocrine tumor with ectopic adrenocorticotropin production upon second recurrence. J Clin Endocrinol Metab. 2004:89(8):3731-6.
32. Singer J, Werner F, Koch CA, Bartels M, Aigner T, Lincke T, Fasshauer M, Paschke R. Ectopic Cushing's syndrome caused by a well differentiated ACTH-secreting neuroendocrine carcinoma of the ileum. Exp Clin Endocrinol Diabetes. 2010;118(8):524-9.

33. Oelkers W, Bähr V, Hensen J, Pickartz H. Primary adrenocortical micronodular adenomatosis causing Cushing's syndrome. Effects of ketoconazole on steroid production and in vitro performance of adrenal cells. Acta Endocrinol (Copenh). 1986;113(3):370-7.

34. Walz MK, Peitgen K, Diesing D, Petersenn S, Janssen OE, Philipp T, Metz KA, Mann K, Schmid KW, Neumann HP. Partial versus total adrenalectomy by the posterior retroperitoneoscopic approach: early and long-term results of 325 consecutive procedures in primary adrenal neoplasias. World J Surg. 2004;28(12):1323-9.

35. Fleseriu M, Biller BM, Findling JW, Molitch ME, Schteingart DE, Gross C, SEISMIC Study Investigators. Mifepristone, a glucocorticoid receptor antagonist, produces clinical and metabolic benefits in patients with Cushing's syndrome. J Clin Endocrinol Metab. 2012;97(6):2039-49.

36. Fleseriu M, Findling JW, Koch CA, Schlaffer SM, Buchfelder M, Gross C. Changes in plasma ACTH levels and corticotroph tumor size in patients with Cushing's disease during long-term treatment with the glucocorticoid receptor antagonist mifepristone. J Clin Endocrinol Metab. 2014;99(10):3718-27.

37. Melcescu E, Griswold M, Xiang L, Belk S, Montgomery D, Bray M, Del Ben KS, Uwaifo GI, Marshall GD, Koch CA. Prevalence and cardiometabolic associations of the glucocorticoid receptor gene polymorphisms N363S and $\mathrm{BCll}$ in obese and non-obese black and white Mississippians. Hormones (Athens). 2012;11(2):166-77.

38. Uwaifo Gl, Melcescu E, McDonald A, Koch CA. A case of profound weight loss secondary to use of phentermine. J Miss State Med Assoc. 2009; 50(12):407-15.

39. Mohammed R, Norton J, Geraci SA, Newman DB, Koch CA. Prolonged QTc interval due to escitalopram overdose. J Miss State Med Assoc. 2010;51(12):350-3.

40. Newman BD, Maher JF, Subauste JS, Uwaifo Gl, Bigler SA, Koch CA. Clustering of sebaceous gland carcinoma, papillary thyroid carcinoma and breast cancer in a woman as a new cancer susceptibility disorder: a case report. J Med Case Rep. 2009;3:6905. https://doi.org/10.4076/1752-1947-3-6905.

41. Gharaibeh KA, Craig MJ, Koch CA, Lerant AA, Fülöp T, Csongrádi E. Desmopression is an effective adjunct treatment for reversing excessive hyponatremia overcorrection. World J Clin Cases. 2013;1(5):155-8.

42. Koch CA, Fülöp T. Clinical aspects of changes in water and sodium homeostasis in the elderly. Rev Endocr Metab Disord. 2017;18(1):49-66.

43. Fülöp T, Koch CA, Farah Musa AR, Clark CM, Gharaibeh KA, Lengvársky Z, Hamrahian M, Pitman KT, Dixit MP. Targeted surgical parathyroidectomy in end-stage renal disease patients and long-term metabolic control: A singlecenter experience in the current era. Hemodial Int. 2018;22(3):394-404.

44. Kumar E, McCurdy MT, Koch CA, Hamadah A, Fülöp T, Gharaibeh KA Impairment of Thyroid Function in Critically III Patients in the Intensive Care Units. Am J Med Sci. 2018;355(3):281-5.

45. Fülöp T, Koch CA, Norris LT, Rodríguez B, Szarvas T, Lengvárszky Z, Csongrádi É, Dixit MP. Uric Acid Control in Advanced Chronic Kidney Disease in a Southeastern US Urban Cohort. South Med J. 2018;111(9):549-55.

46. Koch CA, Petersenn S. Black swans - neuroendocrine neoplasms of rare locations. Rev Endocr Metab Disord. 2018; https://doi.org/10.1007/s11154018-9473-0. 19(2):111-121

Ready to submit your research? Choose BMC and benefit from:

- fast, convenient online submission

- thorough peer review by experienced researchers in your field

- rapid publication on acceptance

- support for research data, including large and complex data types

- gold Open Access which fosters wider collaboration and increased citations

- maximum visibility for your research: over $100 \mathrm{M}$ website views per year

At $\mathrm{BMC}$, research is always in progress.

Learn more biomedcentral.com/submission 